\title{
KNOWLEDGE, AWARENESS, AND PRACTICES REGARDING BIOMEDICAL WASTE MANAGEMENT AMONG UNDERGRADUATE DENTAL STUDENTS
}

\author{
SANTHOSH KUMAR MP*, RESHMA RAHMAN \\ Department of Oral and Maxillofacial Surgery, Saveetha Dental College and Hospital, Velappanchavadi, Chennai, Tamil Nadu, India. \\ Email: santhoshsurgeon@gmail.com
}

Received: 12 April 2017, Revised and Accepted: 17 May 2017

\section{ABSTRACT}

Objective: The objective of this study was to assess the knowledge, awareness, and practices of dental students regarding biomedical waste (BMW) management.

Methods: A self-administered structured questionnaire consisting of 16 questions on knowledge, awareness, and practices about BMW management was distributed among 100 students randomly belonging to $3^{\text {rd }}$ year, final year and intern students of Saveetha Dental College, Saveetha University, Chennai. The data extracted were tabulated, statistically analyzed using SPSS version 20.0 and results obtained. The data were analyzed using ANOVA test (all the results are calculated at 1\% level of significance) and Post-hoc test.

Results: Overall, $67 \%$ respondents were aware of the existing BMW management policy systems in India. $62 \%$ of students were aware about the correct color coding management system for hospital waste management that prevails in India. $86 \%$ of students knew about the dental waste categories of materials used in dentistry. There was a statistically significant difference of knowledge levels among the $3^{\text {rd }}$ year, final year students and the interns. $100 \%$ practice discarding sharps in the puncture-proof containers. Only $27 \%$ of the respondents discarded the extracted tooth in a proper way. Only $51 \%$ of them have attended previous training programs on dental waste management. There was also a statistically significant difference of BMW disposal practices among the three groups.

Conclusion: The majority of dental students in our study have good level of knowledge and awareness regarding BMW management in dental clinics. However, their practice toward BMW disposal was poor. Hence, the knowledge acquired must be put into practice. Intern students have the highest level of knowledge and practices toward dental waste disposal when compared to final year and $3^{\text {rd }}$ year students. Hence, these findings imply that proper training, continuing education programs, and short-term courses about BMW management, and infection control procedures are required to motivate the dental students and dental auxiliaries. The importance of training regarding BMW management must be emphasized as the lack of proper and complete knowledge about BMW management impacts practices of appropriate waste disposal.

Keywords: Biomedical waste management, Health hazard, Knowledge, Attitude, Dental students, Practices, Waste disposal.

(C) 2017 The Authors. Published by Innovare Academic Sciences Pvt Ltd. This is an open access article under the CC BY license (http://creativecommons. org/licenses/by/4. 0/) DOI: http://dx.doi.org/10.22159/ajpcr.2017.v10i8.19101

\section{INTRODUCTION}

Healthcare waste is a heterogeneous mixture, which is very difficult to manage. Waste generated in a dental teaching hospital is similar to that generated by other hospitals, which includes a large component of general waste and a smaller proportion of hazardous waste. According to biomedical waste (BMW) (Management and Handling) rules, 1998 of India "any waste which is generated during the diagnosis, treatment or immunization of human beings or animals or in research activities pertaining thereto or the production or testing of biological [1].

Dental professionals are at a greater risk for acquiring cross-infection while treating patients. This is evident from the fact that most of the human pathogens have been isolated from oral secretions. Dental hospitals use instruments and materials that are directly exposed to blood and saliva and are therefore potential sources of infection. Many chemicals such as acrylics, impression materials, and mercury used for restorative purposes may have a possible environmental and human health impact if not handled properly [2].

A major issue related to present BMW management is that many hospitals dispose their waste in an improper, haphazard and indiscriminate manner which contributes to spread of serious diseases such as hepatitis and human immunodeficiency virus [3]. Although India has well-established protocols for handling and management of BMWs, namely, the BMW (management and handling) Amendment Rules, 2000, but still there is a great lack of knowledge, awareness, attitude and practice of proper waste management among various health-care professionals [4].

Thus, with this background, this study was conducted to assess the knowledge, awareness, attitude, and practices among the undergraduate dental students of our institution regarding biomedical waste management.

\section{METHODS}

A cross-sectional study was conducted during the academic year in October 2016 among the undergraduate dental students of Saveetha Dental College, Saveetha University, Chennai. A total of 100 students were randomly enrolled in the study including $3^{\text {rd }}$ year, final year and intern students. All students in the study voluntarily completed the questionnaire consisting of 16 close-ended questions. The questionnaire included 10 knowledge and awareness related questions, 6 practice related questions to assess the knowledge, awareness, and practices of dental students about BMW management. The questions were pretested for reliability and validity.

Questionnaire: Knowledge, Awareness, and Practices about BMW management among undergraduate dental students. 
Knowledge and awareness related questions:

1. Where should the dental waste be disposed?

- Certified waste carrier service

- Common dust bin

- Open areas

2. The color coding for hospital waste given by BMW management in India is:

- Yellow, Red, White, and Black

- Yellow, Blue, Green, and Black

- Red, White, Black, and Green

3. The most effective way to remove accidental spill of mercury in the clinic is:

- Mercury spill kit

- Common dust bin

- Hydrogen peroxide solution

4. The cotton gauge used during extraction can be disposed by

- Burnt

- Dustbin

- Open area

5. Extracted tooth and used impression materials come under infected category?

- Yes

- No

6. Outdated and contaminated medicines come under cytotoxic/ chemical waste category?

- Yes

- No

7. What do you think are the most common problems in the management of healthcare waste in your clinic?

- Lack of information

- Nonavailability of agency service

- Not well trained

8. Are you aware of the existing medical waste management policy in India?

- Yes

- $\mathrm{No}$

9. Have you attended any previous training programs on dental waste management?

- Yes

- No

10. Do you think you need more training regarding dental waste management?

- Yes

- No

Practice related questions:

11. Which color code bag do you use to dispose syringes, needles, scalpels?

- White

- Yellow

- Red

12. Do you use puncture-proof containers to discard needles in your clinic?

- Yes

- No

13. Do you segregate the waste before disposal?

- Yes

- No

14. Do you hand over dental waste to the municipal garbage collector?

- Yes

- No

15. Do you discard extracted teeth directly into regular garbage?

- Yes

- No

16. Do you follow manufacturer's recommendations on disposal of used fixer solution?

- Yes

- No

For every correct answer a score of 1 was assigned and a score of 0 for every incorrect answer. Total score of $75 \%$ and above, between $50 \%$ and $75 \%$, between $25 \%$ and $50 \%$ and score $<25 \%$ was considered as excellent, good, moderate and weak knowledge, respectively. Similarly, their practices toward BMW management were also graded based on their responses. Data collected, statistical analyses for knowledge, awareness and practices, descriptive statistics were computed and results obtained. Data management and statistical analysis were performed using the statistical software SPSS version 20.0. The data obtained were analyzed using ANOVA test (all the results are calculated at $1 \%$ level of significance) and Post-hoc tests.

\section{RESULTS}

The survey was conducted on 100 dental students out of which 27 were $3^{\text {rd }}$ year students, 39 from final year and 34 were doing internship. The knowledge score according to the year of study was $66.7 \%, 51.3 \%$ and $79.4 \%$ for $3^{\text {rd }}, 4^{\text {th }}$ years and interns, respectively (Tables 1 and 2). Overall, 67\% respondents were aware of the existing BMW management policy systems in India. $62 \%$ of students were aware about the correct color coding management system for hospital waste management that prevails in India. $65 \%$ were aware about the methods of removing accidental spills of mercury, and $79 \%$ of them had correct knowledge about the disposal of cotton used during extraction. $86 \%$ of students knew about the dental waste categories of materials used in dentistry. Only $51 \%$ of them have attended previous training programs on dental waste management. $80 \%$ of the respondents said that they needed more information on BMW practices (Table 3 ).

Only $5 \%$ of them handed over the daily dental waste properly to the municipal garbage collection center. Only $27 \%$ of the respondents discarded the extracted tooth in a proper way. $41 \%$ of dental students were not disposing the needles, syringes and sharps in the correct color coded bags. However, $100 \%$ of the students followed the manufacturer's recommendations on disposal of used fixer solution, and all of them segregated the waste material before disposal. Furthermore, $100 \%$ of students used puncture proof containers for discarding used needles (Table 4).

Table 1: Knowledge levels of respondents regarding BMW management

\begin{tabular}{|c|c|c|c|c|}
\hline \multicolumn{3}{|c|}{ Level of knowledge * year cross tabulation } & \multirow{2}{*}{$\begin{array}{l}\text { Year } \\
\text { Intern }\end{array}$} & \multirow[t]{2}{*}{ Total } \\
\hline Level of knowledge & $3^{\text {rd }}$ year & $4^{\text {th }}$ year & & \\
\hline \multicolumn{5}{|l|}{ Poor knowledge } \\
\hline Count & 3 & 8 & 2 & 13 \\
\hline \% within year & 11.1 & 20.5 & 5.9 & 13.0 \\
\hline \multicolumn{5}{|l|}{ Moderate knowledge } \\
\hline Count & 5 & 1 & 5 & 11 \\
\hline$\%$ within year & 18.5 & 2.6 & 14.7 & 11.0 \\
\hline \multicolumn{5}{|l|}{ Good knowledge } \\
\hline Count & 1 & 10 & 0 & 11 \\
\hline$\%$ within year & 3.7 & 25.6 & 0.0 & 11.0 \\
\hline \multicolumn{5}{|l|}{ Excellent knowledge } \\
\hline Count & 18 & 20 & 27 & 65 \\
\hline$\%$ within year & 66.7 & 51.3 & 79.4 & 65.0 \\
\hline \multicolumn{5}{|l|}{ Total } \\
\hline Count & 27 & 39 & 34 & 100 \\
\hline$\%$ within year & 100.0 & 100.0 & 100.0 & 100.0 \\
\hline
\end{tabular}

BMW: Biomedical waste

Table 2: Chi-Square Tests

\begin{tabular}{llll}
\hline Correlation & Value & df & $\begin{array}{l}\text { Asymp. } \\
\text { significant (2-sided) }\end{array}$ \\
\hline Pearson Chi-square & $22.301^{\mathrm{a}}$ & 6 & 0.001 \\
Likelihood ratio & 25.376 & 6 & 0.000 \\
Linear-by-linear association & 1.113 & 1 & 0.291 \\
Number of valid cases & 100 & & \\
\hline a8 cells (66.7\%) have expected count <5. The minimum expected count is 2.97
\end{tabular}


Table 3: Correct knowledge and awareness of respondents regarding hospital waste management [correct responses]

\begin{tabular}{|c|c|c|c|c|}
\hline Questions & $3^{\text {rd }}$ years & Final years & Interns & Total \\
\hline Where should the dental waste be disposed? & $16(59.3)$ & $31(79.5)$ & $27(79.5)$ & 74 \\
\hline The color coding for hospital waste given by BMW management in India is & $19(70.4)$ & $20(51.3)$ & $23(67.6)$ & 62 \\
\hline The most effective way to remove accidental spill of mercury in the clinic is & $20(74.1)$ & $18(46.2)$ & $27(79.4)$ & 65 \\
\hline The cotton gauge used during extraction can be disposed in & $18(66.7)$ & $32(82.1)$ & $29(85.3)$ & 79 \\
\hline Extracted tooth and used impression materials comes under infected category & $24(88.9)$ & $30(76.9)$ & $32(94.1)$ & 86 \\
\hline Outdated and contaminated medicines comes under cytotoxic/chemical waste category & $24(88.9)$ & $30(76.9)$ & $32(94.1)$ & 86 \\
\hline $\begin{array}{l}\text { What do you think the most common problems in the management of healthcare waste in } \\
\text { your clinic? }\end{array}$ & $21(77.7)$ & $30(76.9)$ & $29(85.3)$ & 80 \\
\hline Are you aware of the existing medical waste management policy in India? & $21(77.8)$ & $22(56.4)$ & $24(70.6)$ & 67 \\
\hline Have you attended any previous training programs on dental waste management? & $14(51.9)$ & $19(48.7)$ & $34(52.9)$ & 51 \\
\hline Do you think you need more training regarding dental waste management? & $26(96.3)$ & 23 (59) & 31 (91.2) & 80 \\
\hline
\end{tabular}

Table 4: Correct practices of respondents regarding BMW management [correct responses]

\begin{tabular}{|c|c|c|c|c|}
\hline Questions & $3^{\text {rd }}$ years & Final years & Interns & Total \\
\hline Which color code bag do you use to dispose syringes, needles, scalpels? & $17(63)$ & $20(51.3)$ & $22(64.7)$ & 59 \\
\hline Do you use puncture proof containers to discard needles in your clinic? & $27(100)$ & $39(100)$ & $34(100)$ & 100 \\
\hline Do you segregate the waste before disposal? & $27(100)$ & $39(100)$ & $34(100)$ & 100 \\
\hline Do you hand over dental waste to the municipal garbage collector? & $5(18.5)$ & $0(0)$ & $0(0)$ & 5 \\
\hline Do you discard extracted teeth directly into regular garbage? & $11(40.7)$ & $15(38.5)$ & $1(2.9)$ & 27 \\
\hline Do you follow manufacturer's recommendations on disposal of used fixer solution? & $27(100)$ & $39(100)$ & $34(100)$ & 100 \\
\hline
\end{tabular}

Table 5: One-way descriptives

\begin{tabular}{|c|c|c|c|c|c|c|c|}
\hline \multirow[t]{2}{*}{ Year } & \multirow[t]{2}{*}{$N$} & \multirow[t]{2}{*}{ Mean $\pm S D$} & \multirow[t]{2}{*}{ Standard error } & \multicolumn{2}{|c|}{$\begin{array}{l}95 \% \text { confidence interval for } \\
\text { mean }\end{array}$} & \multirow[t]{2}{*}{ Minimum } & \multirow[t]{2}{*}{ Maximum } \\
\hline & & & & Lower bound & Upper bound & & \\
\hline \multicolumn{8}{|c|}{ Knowledge (\%) } \\
\hline $3^{\text {rd }}$ year & 27 & $74.69 \pm 36.506$ & 7.026 & 60.25 & 89.13 & 0 & 100 \\
\hline $4^{\text {th }}$ year & 39 & $68.80 \pm 38.079$ & 6.097 & 56.46 & 81.15 & 0 & 100 \\
\hline Intern & 34 & $83.33 \pm 30.151$ & 5.171 & 72.81 & 93.85 & 0 & 100 \\
\hline \multicolumn{8}{|c|}{ Awareness (\%) } \\
\hline $3^{\text {rd }}$ year & 27 & $75.93 \pm 23.495$ & 4.522 & 66.63 & 85.22 & 25 & 100 \\
\hline $4^{\text {th }}$ year & 39 & $60.26 \pm 41.643$ & 6.668 & 46.76 & 73.76 & 0 & 100 \\
\hline Intern & 34 & $75.00 \pm 33.143$ & 5.684 & 63.44 & 86.56 & 0 & 100 \\
\hline Total & 100 & $69.50 \pm 35.101$ & 3.510 & 62.54 & 76.46 & 0 & 100 \\
\hline \multicolumn{8}{|c|}{ Practice (\%) } \\
\hline $3^{\text {rd }}$ year & 27 & $73.46 \pm 13.285$ & 2.557 & 68.20 & 78.71 & 50 & 83 \\
\hline $4^{\text {th }}$ year & 39 & $68.80 \pm 15.848$ & 2.538 & 63.67 & 73.94 & 50 & 83 \\
\hline Total & 100 & $72.83 \pm 13.537$ & 1.354 & 70.15 & 75.52 & 50 & 83 \\
\hline
\end{tabular}

SD: Standard deviation

Comparisons of knowledge, awareness and practices between the three groups are shown in Tables 5-7. Correlations are shown in Tables 8-10.

\section{DISCUSSION}

The waste produced in the course of health-care activities carries a higher potential for infection and injury than any other type of waste. Inadequate and inappropriate knowledge of handling of healthcare waste may have serious health consequences and a significant impact on the environment as well. Infectious, chemical and hazardous contents in dental healthcare waste make its management very complex. Poor dental waste management exposes the workers of health-care facility, waste handlers and community as a whole to infection, toxic effect and injury [4]. Lack of information leads the dental professionals to contribute toward environment degradation. This study was a small effort to assess the knowledge and awareness of dental students toward dental waste management.

In our study, the majority of the dental undergraduates were aware of the term "BMW management" and $67 \%$ of them were aware about the existing BMW management policy in India. This is in agreement with
Table 6: ANOVA

\begin{tabular}{llllll}
\hline Relation & $\begin{array}{l}\text { Sum of } \\
\text { squares }\end{array}$ & df & $\begin{array}{l}\text { Mean } \\
\text { square }\end{array}$ & F & Significant \\
\hline Knowledge (\%) & & & & & \\
$\quad$ Between groups & 3850.079 & 2 & 1925.040 & 1.559 & 0.216 \\
$\quad$ Within groups & 119749.921 & 97 & 1234.535 & & \\
$\quad$ Total & 123600.000 & 99 & & & \\
Awareness (\%) & & & & & \\
$\quad$ Between groups & 5475.712 & 2 & 2737.856 & 2.280 & 0.108 \\
Within groups & 116499.288 & 97 & 1201.024 & & \\
$\quad \begin{array}{l}\text { Total } \\
\text { Practice (\%) }\end{array}$ & 121975.000 & 99 & & & \\
$\quad$ Between groups & 1223.082 & 2 & 611.541 & 3.506 & 0.034 \\
$\quad$ Within groups & 16918.585 & 97 & 174.418 & & \\
$\quad$ Total & 18141.667 & 99 & & & \\
\hline
\end{tabular}

the study conducted by Charania and Ingle [5], in which $72 \%$ of dentists knew about the BMW management and handling laws in India, and both these studies were conducted in Chennai, Tamil Nadu. 
Table 7: Post-hoc tests multiple comparisons

\begin{tabular}{|c|c|c|c|c|c|c|c|}
\hline \multicolumn{8}{|l|}{ Turkey HSD } \\
\hline \multirow[t]{2}{*}{ Dependent variable } & \multirow[t]{2}{*}{ (I) Year } & \multirow[t]{2}{*}{ (J) Year } & \multirow[t]{2}{*}{ Mean difference (I-J) } & \multirow[t]{2}{*}{ Standard error } & \multirow[t]{2}{*}{ Significant } & \multicolumn{2}{|c|}{$95 \%$ confidence interval } \\
\hline & & & & & & Lower bound & Upper bound \\
\hline \multirow[t]{5}{*}{ Knowledge (\%) } & \multirow[t]{2}{*}{$3^{\text {rd }}$ year } & $4^{\text {th }}$ year & 5.888 & 8.796 & 0.782 & -15.05 & 26.83 \\
\hline & & Intern & -8.642 & 9.057 & 0.608 & -30.20 & 12.92 \\
\hline & \multirow{2}{*}{$4^{\text {th }}$ year } & $3^{\text {rd }}$ year & -5.888 & 8.796 & 0.782 & -26.83 & 15.05 \\
\hline & & Intern & -14.530 & 8.244 & 0.188 & -34.15 & 5.09 \\
\hline & Intern & $4^{\text {th }}$ year & 14.530 & 8.244 & 0.188 & -5.09 & 34.15 \\
\hline \multirow[t]{6}{*}{ Awareness (\%) } & \multirow[t]{2}{*}{$3^{\text {rd }}$ year } & $4^{\text {th }}$ year & 15.670 & 8.676 & 0.173 & -4.98 & 36.32 \\
\hline & & Intern & 0.926 & 8.933 & 0.994 & -20.34 & 22.19 \\
\hline & \multirow[t]{2}{*}{$4^{\text {th }}$ year } & $3^{\text {rd }}$ year & -15.670 & 8.676 & 0.173 & -36.32 & 4.98 \\
\hline & & Intern & -14.744 & 8.131 & 0.171 & -34.10 & 4.61 \\
\hline & \multirow[t]{2}{*}{ Intern } & $3^{\text {rd }}$ year & -0.926 & 8.933 & 0.994 & -22.19 & 20.34 \\
\hline & & $4^{\text {th }}$ year & 14.744 & 8.131 & 0.171 & -4.61 & 34.10 \\
\hline \multirow[t]{5}{*}{ Practice (\%) } & $3^{\text {rd }}$ year & $4^{\text {th }}$ year & 4.653 & 3.306 & 0.341 & -3.22 & 12.52 \\
\hline & \multirow[t]{2}{*}{$4^{\text {th }}$ year } & $3^{\text {rd }}$ year & -4.653 & 3.306 & 0.341 & -12.52 & 3.22 \\
\hline & & Intern & $-8.157^{*}$ & 3.099 & 0.026 & -15.53 & -0.78 \\
\hline & \multirow{2}{*}{ Intern } & $3^{\text {rd }}$ year & 3.504 & 3.404 & 0.560 & -4.60 & 11.61 \\
\hline & & $4^{\text {th }}$ year & $8.157^{*}$ & 3.099 & 0.026 & 0.78 & 15.53 \\
\hline
\end{tabular}

*The mean difference is significant at the 0.05 level

Table 8: Correlations descriptive statistics

\begin{tabular}{lll}
\hline Parameter & Mean \pm SD & N \\
\hline Knowledge & $4.52 \pm 2.120$ & 100 \\
Awareness & $2.78 \pm 1.404$ & 100 \\
Practice & $4.37 \pm 0.812$ & 100 \\
\hline
\end{tabular}

SD: Standard deviation

Table 9: Correlations

\begin{tabular}{|c|c|c|c|}
\hline & Knowledge & Awareness & Practice \\
\hline \multicolumn{4}{|l|}{ Knowledge } \\
\hline Pearson correlation & 1 & $0.768^{* *}$ & $0.837^{* *}$ \\
\hline Significant (2-tailed) & & 0.000 & 0.000 \\
\hline $\mathrm{N}$ & 100 & 100 & 100 \\
\hline \multicolumn{4}{|l|}{ Awareness } \\
\hline Pearson correlation & $0.768 * *$ & 1 & $0.852 * *$ \\
\hline Significant (2-tailed) & 0.000 & & 0.000 \\
\hline $\mathrm{N}$ & 100 & 100 & 100 \\
\hline \multicolumn{4}{|l|}{ Practice } \\
\hline Pearson correlation & $0.837^{* *}$ & $0.852^{* *}$ & 1 \\
\hline Significant (2-tailed) & 0.000 & 0.000 & \\
\hline $\mathrm{N}$ & 100 & 100 & 100 \\
\hline
\end{tabular}

**Correlation is significant at the 0.01 level (2-tailed)

Table 10: Nonparametric correlations

\begin{tabular}{|c|c|c|c|}
\hline Kendall's tau_b & Knowledge & Awareness & Practice \\
\hline \multicolumn{4}{|l|}{ Knowledge } \\
\hline Correlation coefficient & 1.000 & $0.747^{* *}$ & $0.849^{* *}$ \\
\hline Significant (2-tailed) & & 0.000 & 0.000 \\
\hline $\mathrm{N}$ & 100 & 100 & 100 \\
\hline \multicolumn{4}{|l|}{ Awareness } \\
\hline Correlation coefficient & $0.747^{* *}$ & 1.000 & $0.801^{* *}$ \\
\hline Significant (2-tailed) & 0.000 & & 0.000 \\
\hline $\mathrm{N}$ & 100 & 100 & 100 \\
\hline \multicolumn{4}{|l|}{ Practice } \\
\hline Correlation coefficient & $0.849^{* *}$ & $0.801^{* *}$ & 1.000 \\
\hline Significant (2-tailed) & 0.000 & 0.000 & \\
\hline $\mathrm{N}$ & 100 & 100 & 100 \\
\hline
\end{tabular}

**Correlation is significant at the 0.01 level (2-tailed)

About $86 \%$ of students in our study knew about the categories of dental waste materials generated in the clinics, which is similar to the study by
Sudhir [6], Charania and Ingle, [5] and Bansal et al. [7] in which 89\%, $85 \%$, and $86 \%$ of dental practitioners, respectively, were aware of the BMW categories. $79 \%$ of our students were aware of the methods of segregating and disposing extracted tooth and the cotton soaked in saliva and blood.

In our study, $62 \%$ of students were aware about the correct color coding for hospital waste management, whereas $72 \%$ of participants knew about the color coding systems in the studies conducted by Sudhir [6] and Charania and Ingle [5]. In contrary, a higher proportion of dentists $(88 \%)$ were aware about the color coding system according to the study by Bansal et al. [7]. In our study, the majority of students had a good level of knowledge and awareness regarding BMW management. Intern students had the highest level of knowledge and awareness toward dental waste management when compared to final year and $3^{\text {rd }}$ year students.

In this study, $51 \%$ of them have attended previous training programs on dental waste management, whereas only $16.3 \%$ of the respondents agreed that they had received training in BMW management in the study reported by Sanjeev et al. [8]. 80\% of students in our study felt they need more training on BMW management, whereas $97 \%$ were interested in receiving further training on the same according to the study by Sanjeev et al. [8]. Thus, overall students showed a very positive attitude toward healthcare waste management.

Maximum care and precaution are required to handle sharps as improper handling can lead to various health hazards. The needles, which comprised the bulk of "sharps," should be destroyed by needle destroyers and should be placed in puncture-proof container containing $1 \% \mathrm{NaOCl}$ for disinfection. Once the container is three- $4^{\text {th }}$ filled, it should be sent for shredding, encapsulation, and disposal in landfills. $100 \%$ of our students used puncture-proof containers for discarding used needles. This shows that our study participants have excellent knowledge and practices regarding discarding needles. This was much higher than the results observed by Mathur et al. [9], Bansal et al. [7], and Chudasama et al. [10] where only around $65.3 \%, 58 \%$, and $63.1 \%$ used to dispose sharps in puncture-proof containers. Whereas only $41.7 \%$ and $26.4 \%$ of study participants disposed needles in puncture proof containers according to the study by Manchanda et al. [11] and Charania and Ingle [5], respectively.

In the present study, $100 \%$ of the participants agreed that they segregate the waste before disposal. This is much higher than what was 
reported by Sanjeev et al. [8] (96.6\%), Chudasama et al. [10] (96.5\%), Manchanda et al. [11] (90\%), and Mathur et al. [9] (81.3\%). However, in the study by Bansal et al. [7], only $76 \%$ of the dentists segregated different wastes according to the laws of BMW management.

In our study, only $5 \%$ of them handed over the daily dental waste properly to the municipal garbage collection center. Only $27 \%$ of the respondents discarded the extracted tooth in a proper way. $41 \%$ of dental students were not disposing the needles, syringes and sharps in the correct color coded bags. Thus, the majority of the students in this study did not practice proper dental waste segregation and disposal methods, although intern students exhibited better practices compared to final year and $3^{\text {rd }}$ year students. Although most of our dental students were aware of the hazardous effect of improper disposal, a large proportion of them did not practice proper methods of BMW disposal, which is similar to the studies by Bansal et al. [7], Sanjeev et al. [8], Manchanda et al. [11], and Bangennavar et al. [12].

Waste disposal is more of a social responsibility than a legal obligation. The present scenario of knowledge about waste disposal is not adequate, and the practice of proper waste disposal is even poorer. The role of dentists starts from reduction in the quantity of waste disposed. All efforts should be directed toward appropriate and cost-effective waste management. Safe and effective management of waste is not only a legal necessity but also a social responsibility. Continuing education and training programs and short courses on cross-infection and BMW management are suitable means of improving the knowledge of dental students who will be the future dentists and other staff employed in various dental teaching hospitals. Various demonstration programs should be conducted for those personnel who are in direct contact of BMW to increase their level of understanding and associated risks [13].

More emphasis should be laid on BMW management as a lack of knowledge on healthcare waste impacts practices of appropriate waste disposal $[10,14]$. Dental auxiliaries work in close association with dentists, and they also have an important role in the healthcare waste management. In a study, it was shown that there was a lack of awareness of most aspects of BMW management among dental auxiliary staff in the dental hospital/clinics in Amritsar [15]. Hence, they should be motivated to attend training and CDE programs concerning waste management so that they will be efficient to properly segregate, disinfect, and dispose hospital waste in an eco-friendly way [16].

BMW management should be strictly implemented and monitored in a systematic and simplistic manner by authoritative bodies in India and other developing countries [7]. A study by Bennadi et al. [17] showed that most of the dentists in Bellary were well aware of the hazards; they can come across in Dentistry, and most of them were taking necessary steps to combat the problems in the form of physical exercise, vaccination, proper dental waste disposal, usage of preventive barriers as well as following ethical principles. The governmental bodies should take responsibility of making these services available to the practicing dentists as well as dental hospitals. We recommend that there should be proper and intensive training programs regarding awareness and practices of waste disposal for all health-care staff and students with continuous monitoring at regular intervals. BMW management should be compulsorily made as part of the dental undergraduate curriculum. Further research must be undertaken to seal existing gaps in the knowledge about hospital waste management. The findings of this study will help to address the issue more appropriately and inform plans for better training programs and monitoring of BMW management systems in dental institutions.

\section{CONCLUSION}

The majority of dental students in our study have a good level of knowledge and awareness regarding BMW management in dental clinics. However, their practice toward BMW disposal was poor. Hence, the knowledge acquired must be put into practice. Intern students have the highest level of knowledge and practices toward dental waste disposal when compared to final year and $3^{\text {rd }}$ year students. Hence, these findings imply that proper training, continuing education programs and short-term courses about BMW management and infection control procedures are required to motivate the dental students and dental auxiliaries. The importance of training regarding BMW management must be emphasized as the lack of proper and complete knowledge about BMW management impacts practices of appropriate waste disposal.

\section{REFERENCES}

1. Government of India. Biomedical Waste (Management and Handling) Rules, 1998. Extraordinary, Part II, Section 3, Subsection (II). The Gazette of India. No.460. New Delhi: Government of India; 1998.

2. Sood AG, Sood A. Dental perspective on biomedical waste and mercury management: A knowledge, attitude, and practice survey. Indian J Dent Res 2011;22(3):371-5.

3. Zia A, Ullah I, Ali S, Zia M, Mathew S, Fatima K, et al. Prevalent risk factors of $\mathrm{HCV}$ transmission in health care workers (HCWS) in Pakistan. Int J Pharm Pharm Sci 2015;7(11):365-70.

4. Mathur P, Patan S, Shobhawat SA. Need of biomedical waste management system in hospitals - An emerging issue - A review. Curr world Environ 2012;7(1):117-24.

5. Charania ZK, Ingle NA. Awareness and practice of dental care management among dental practitioners in Chennai city. J Contemp Dent 2011;1(1):15-21.

6. Sudhir KM. Awareness and practices about dental health care waste management among dentists of Davangere city, Karnataka. J Indian Assoc Public Health Dent 2006;8:44-50.

7. Bansal M, Vashisth S, Gupta N. Knowledge, awareness and practices of dental care waste management among private dental practitioners in Tricity (Chandigarh, Panchkula and Mohali). J Int Soc Prev Community Dent 2013;3(2):72-6

8. Sanjeev R, Kuruvilla S, Subramaniam R, Prashant PS, Gopalakrishnan M. Knowledge, attitude, and practices about biomedical waste management among dental healthcare personnel in dental colleges in Kothamangalam: A cross-sectional study. Health Sci 2014;1(3):1-12.

9. Mathur V, Dwivedi S, Hassan M, Misra R. Knowledge, attitude, and practices about biomedical waste management among healthcare personnel: A cross-sectional study. Indian J Community Med 2011;36(2):143-5

10. Chudasama RK, Rangoonwala M, Sheth A, Misra SK, Kadri AM, Patel UV. Biomedical waste management: A study of knowledge, attitude and practice among health care personnel at tertiary care hospital in Rajkot. J Res Med Dent Sci 2013;1(1):17-22.

11. Manchanda K, Fotedar S, Dahiya P, Vats A, De Sarkar A, Vats AS. Knowledge, attitude, and practices about biomedical waste management among dental healthcare personnel in dental colleges in Himachal Pradesh: A cross-sectional study. SRM J Res Dent Sci 2015;6(3):166-9.

12. Bangennavar BF, Gupta A, Khullar S, Sukla N, Das A, Atram P. Biomedical waste disposal: Practice, knowledge, and awareness among dentists in India. J Int Oral Health 2015;7(11):53.

13. Pandit NB, Mehta HK, Kartha GP, Choudhary SK. Management of biomedical waste: Awareness and practices in a district of Gujarat. Indian J Public Health 2005;49(4):245-7.

14. Madhukumar S, Ramesh G. Study about awareness and practices about health care wastes management among hospital staff in a medical college hospital, Bangalore. Int J Basic Med Sci 2012;3:7-11.

15. Narang RS, Manchanda A, Singh S, Verma N, Padda S. Awareness of biomedical waste management among dental professionals and auxiliary staff in Amritsar, India. Oral Health Dent Manag 2012;11(4):162-8.

16. Khatoon KF, Akkifuddin S. Awareness of dental auxillaries in biomedical waste disposal: A survey. J Adv Med Dent Sci Res 2015;3(1):40.

17. Bennadi D, Reddy V, Thummala NR. Preventive and curative measures adopted by dentists to combat occupational hazards-a cross sectional study. Int J Pharm Pharm Sci 2015;7(10):416-8. 